\title{
PRESENT STATUS OF SUNFLOWER DOWIY MILDEW DISEASE IN INDIA
}

\author{
S.P. Shirshikar* \\ Oilseeds Research Station, Latur-413 512 (M.S.), India \\ Received: March 14, 2004 \\ Accepted: November 22, 2005
}

\section{SUMMARY}

The sunflower downy mildew in India was reported around 1986 in Marathwada region of Maharashtra States where sunflower is extensively grown. A survey in this region conducted in $1995-96$ revealed $36.67 \%$ disease incidence on farmers' fields. Of the 1944 sunflower genotypes screened against downy mildew in infected plot, eight hybrids and one population that showed resistance to downy mildew and high yield potential were released for commercial cultivation in India. Release of such resistant hybrids has helped to minimize the disease incidence on farmers' fields. The disease incidence has been minimized considerably in farmers' fields.

\section{Key words: sunflower disease, downy mildew, incidence screening, resistant} hybrids

\section{INTRODUCTION}

The cultivated sunflower (Helianthus annuus L.) is one of the three important edible oilseed crops grown in the world, after soybean and groundnut. In India, sunflower was introduced in commercial cultivation around 1969 and within a short span it has reached a level of 2.1 million ha with the annual production of 1.3 million $t$ of seed (Damodaram and Hegde, 2002).

More than 30 diseases have been identified on sunflower (Gulya et al., 1994). Among these, downy mildew caused by the fungus Plasmopara halstedii (Farl.) Berl and de Toni is the most destructive one. The disease has been distributed mainly by seed to all sunflower-growing countries (Leepik, 1966; Viranyi, 1990).

Under Indian conditions, the sunflower crop was free from downy mildew until 1985. However, Ramnath et al. (1981) detected the presence of downy mildew oospores on sunflower seeds imported from Bulgaria. The first appearance of downy mildew was reported from Oilseeds Research Station, Latur, in Marathwada region of Maharashtra State, India, where the crop is extensively grown (Mayee and Patil, 1986). The disease incidence was also reported from adjoining major sunflower growing states like Andhra and Karanataka (Mayee, 1988). In 1995-96, 
Shirshikar (1997) conducted a major survey covering six districts of Marathwada region to establish the status of downy mildew in the farmers' fields. The results revealed that $36.67 \%$ of sunflower fields were infected by downy mildew, with disease intensity ranging from 1 to $30 \%$ (Table 1 ).

Table 1: Downy mildew incidence in various districts of Marathwada region (1995-96)

\begin{tabular}{|c|c|c|c|c|c|c|c|c|}
\hline \multirow[b]{2}{*}{$\begin{array}{l}\text { Name of dis- } \\
\text { trict }\end{array}$} & \multirow{2}{*}{$\begin{array}{l}\text { Total no. } \\
\text { of field } \\
\text { visited }\end{array}$} & \multirow{2}{*}{$\begin{array}{l}\text { No. of } \\
\text { infected } \\
\text { fields }\end{array}$} & \multicolumn{2}{|c|}{ Morden } & \multicolumn{2}{|c|}{ Hybrids } & \multicolumn{2}{|c|}{ Other } \\
\hline & & & $\begin{array}{l}\text { Total no. } \\
\text { of fields } \\
\text { visited }\end{array}$ & $\begin{array}{l}\text { No. of } \\
\text { infected } \\
\text { fields }\end{array}$ & $\begin{array}{l}\text { Total no. } \\
\text { of fields } \\
\text { visited }\end{array}$ & $\begin{array}{l}\text { No. of } \\
\text { infected } \\
\text { fields }\end{array}$ & $\begin{array}{l}\text { Total no. } \\
\text { of fields } \\
\text { visited }\end{array}$ & $\begin{array}{l}\text { No. of } \\
\text { infected } \\
\text { fields }\end{array}$ \\
\hline Latur & 27 & 9 & 16 & 9 & 9 & 0 & 2 & 0 \\
\hline Osmanabad & 6 & 5 & 5 & 4 & 1 & 1 & - & - \\
\hline Beed & 3 & 3 & 3 & 3 & - & - & - & - \\
\hline Parbhani & 2 & 1 & 2 & 1 & - & - & - & - \\
\hline Jalana & 7 & 0 & 6 & 0 & 1 & 0 & - & - \\
\hline Aurangabad & 15 & 4 & 7 & 3 & 6 & 1 & 2 & 0 \\
\hline Total & 60 & 22 & 39 & 20 & 17 & 2 & 4 & 0 \\
\hline Percentage & & 36.67 & & 51.28 & & 11.76 & & 0.0 \\
\hline
\end{tabular}

At Oilseeds Research Station, Latur (M.S.), sunflower seed treatment with $6 \mathrm{~g} /$ $\mathrm{kg}$ of Apron has been recommended for the management of downy mildew. For effective management of the disease through identification of resistant hybrids/varieties, a downy mildew infected plot was established to facilitate the screening work. For this purpose an area of $30 \times 20$ m has been selected and repeatedly sown with downy-mildew-susceptible variety Morden over a period of five years. Infected seedlings were incorporated in the soil to maintain infection level at the plot (Patil et al., 1992). The infected plot was established with the following objectives:

1. Screening for resistant sunflower hybrids, for release in commercial production.

2. Identification of resistance sources to initiate a downy mildew-resistance breeding program.

3. To restrict further spread of the disease by releasing resistant material in commercial production, since the disease is seed-borne in nature.

4. To minimize expenditures on plant protection.

In order to have effective screening of sunflower genotypes against downy mildew in the infected plot, a radical inoculation technique (Patil et al., 1992) was followed. Accordingly, sunflower seeds were soaked in tap water for 30 minutes and than kept in rolled wet blotter paper for a period of 3 days to initiate germination. When radicles attained a length of 2 to $3 \mathrm{~mm}$, the germinated seeds were sprayed with downy mildew sporangial suspension and later sown in the infected plot.

At the time of sowing, one row of each test entry was alternated with a row of downy-mildew-susceptible variety Morden which served as infection row. After germination, all test entries were sprayed on daily basis with downy mildew inoculum for a period of 15 days in order to create maximum disease pressure. 
Thus, after establishing the downy mildew infected plot and standardizing the screening technique, a regular downy mildew screening program has been initiated at Oilseeds Research Station, Latur, through All India Co-ordinated Research Program of Sunflower funded by Indian Council of Agricultural Research (ICAR). To minimize losses due to downy mildew disease on farmers' fields, ICAR made it mandatory to screen all sunflower hybrids/varieties for disease reaction before release in commercial production.

From 1995 to 2004, a total of 2135 sunflower entries (1209 hybrids/populations, 338 germplasm lines, 203 parent lines and 385 ORS Latur entries) were screened for downy mildew reaction in the infected plot at Oilseeds Research Station, Latur. Of the tested material, 604 entries (335 hybrids/populations, 84 germplasm lines, 92 parent lines of 6-D-1 and 93 entries of ORS Latur) were found free from downy mildew (Table 2).

Table 2: Details of the sunflower AICRP entries, germplasm/parent lines and Morden versions tested at ORS, Latur, screened for resistance to downy mildew (1995-2004)

\begin{tabular}{|c|c|c|c|c|}
\hline $\begin{array}{l}\text { Ser. } \\
\text { no. }\end{array}$ & Testing year & Details of the entries tested & $\begin{array}{l}\text { Total no. of } \\
\text { entries }\end{array}$ & $\begin{array}{l}\text { No. of disease- } \\
\text { free entries }\end{array}$ \\
\hline \multirow[t]{3}{*}{$\overline{1}$} & $1995-96$ & Hybrids/ populations & 194 & 36 \\
\hline & & Germplasm lines & 40 & -- \\
\hline & & 6-D-1 male parental line & 203 & 92 \\
\hline \multirow[t]{2}{*}{2} & $1996-97$ & Hybrids/ populations & 117 & 43 \\
\hline & & Germplasm lines & 116 & 18 \\
\hline \multirow[t]{2}{*}{3} & $1997-98$ & Hybrids/ populations & 138 & 43 \\
\hline & & Germplasm lines & 81 & 26 \\
\hline \multirow[t]{2}{*}{$\overline{4}$} & $1998-99$ & Hybrids/ populations & 115 & 11 \\
\hline & & Germplasm lines & 51 & 40 \\
\hline \multirow[t]{2}{*}{5} & $1999-2000$ & Hybrids/ populations & 123 & 26 \\
\hline & & Germplasm lines & 50 & -- \\
\hline \multirow[t]{2}{*}{6} & $2000-2001$ & Hybrids/ populations & 156 & 46 \\
\hline & & Germplasm lines & -- & -- \\
\hline \multirow[t]{2}{*}{7} & $2001-2002$ & Hybrids/ populations & 108 & 35 \\
\hline & & Germplasm lines & -- & -- \\
\hline \multirow[t]{2}{*}{8} & $2002-2003$ & Hybrids/ populations & 80 & 32 \\
\hline & & ORS Latur Morden version & 133 & 37 \\
\hline \multirow[t]{2}{*}{9} & 2003-2004 & Hybrids/ populations & 109 & 39 \\
\hline & & ORS Latur Morden and EC-68414 version & 130 & 48 \\
\hline \multirow[t]{6}{*}{10} & $2004-2005$ & Hybrids/ populations & 69 & 24 \\
\hline & & ORS, Latur & 122 & 8 \\
\hline & Total & Hybrids/ populations & 1209 & 311 \\
\hline & & Germplasm lines & 338 & 84 \\
\hline & & 6-D-1 male parental line & 203 & 92 \\
\hline & & ORS Latur Morden and EC-68414 version & 385 & 85 \\
\hline & Grand Total & & 2135 & 604 \\
\hline
\end{tabular}


Based on the downy mildew resistance reaction and yield potential, the ICAR has released 8 sunflower hybrids and one population for commercial production in the country (Anonymous 1996, 1998, 2000, 2003 and 2004a). A list of the released hybrids/populations is presented in Table 3. Also, ICAR (Anonymous, 1999) rejected the release proposal for sunflower hybrid KBSH-42 as it was found susceptible to downy mildew during screening although it had good yield potential (Table 3a).

Table 3: Sunflower hybrids/varieties identified by ICAR for release based on yield and downy mildew resistance reaction (1996-2004)

\begin{tabular}{llrl}
\hline $\begin{array}{l}\text { Ser. } \\
\text { no. }\end{array}$ & $\begin{array}{l}\text { Sunflower } \\
\text { hybrid/variety }\end{array}$ & Year & \multicolumn{1}{l}{ Remark } \\
\hline 1 & Sungene-85 & $1996 \begin{array}{l}\text { This variety was released during AlCRP workshop held at JNKV, Jabalpur, in } \\
\text { April, 1996. }\end{array}$ \\
\hline 2 & LS-11 & $1998 \begin{array}{l}\text { This variety was released for varietal identification at committee meeting held at } \\
\text { TNAU, Coimbatore, in April, 1998. }\end{array}$ \\
\hline 3 & MSFH-47 & $2000 \begin{array}{l}\text { This hybrid was highly resistant to downy mildew and it was released by ICAR } \\
\text { for variety identification at committee meeting held at PAU, Ludhiana, in April, } \\
2000 .\end{array}$ \\
\hline 4 & $\begin{array}{l}\text { Pro-009 } \\
\text { (Prosun-09) }\end{array}$ & $\begin{array}{l}\text { This hybrid was released for variety identification at committee meeting held at } \\
\text { TANU, Coimbatore, in April, 2003. }\end{array}$ \\
\hline 5 & SH-416 & $2003 \begin{array}{l}\text { This hybrid was identified for variety release atcommittee meeting held at TANU, } \\
\text { Coimbatore, in April, 2003. }\end{array}$ \\
\hline 6 & DRSF-108 & $2003 \begin{array}{l}\text { This variety was identified at ICAR'S variety release committee meeting held at } \\
\text { TANU, Coimbatore, in April, 2003. }\end{array}$ \\
\hline 7 & PCSH-243 & $2004 \begin{array}{l}\text { This hybrid was identified for release in the variety release committee meeting } \\
\text { held at ANG Ranga Agric. University, Hyderabad, on May 18-20, 2004. }\end{array}$ \\
\hline 8 & PRO-011 & $2004 \begin{array}{l}\text { This hybrid was identified for release at the variety release committee meeting } \\
\text { held at ANG Ranga Agric. University, Hyderabad, on May, 18-20, 2004. }\end{array}$ \\
\hline 9 & $\begin{array}{l}\text { SCH-35 * } \\
\text { (Maruti) }\end{array}$ & $2004 \begin{array}{l}\text { Released at Maharashtra State Variety release committee meeting held at } \\
\text { Bombay in Feb. 2003. }\end{array}$ \\
\hline * SCH-35 was released for Maharashtra State
\end{tabular}

Table 3a: Details of sunflower hybrids rejected by ICAR'S variety release committee due to susceptibility to downy mildew

\begin{tabular}{llll}
\hline Ser. no. & Name of hybrid & Year & Remark \\
\hline 1 & KBSH-42 & 1999 & $\begin{array}{l}\text { This hybrid had a high yield potential, but it was suscep- } \\
\text { tible to downy mildew. }\end{array}$ \\
\hline
\end{tabular}

A survey was conducted recently in farmers' fields to assess the present status of sunflower downy mildew. The survey results (Table 4) revealed that in most of the farmers' fields the downy mildew incidence was in traces and in some fields it was below 5.0\% (Anonymous, 2004b). However, during the survey conducted in Marathwada region in 1995-96, the downy mildew disease incidence in farmers' fields was $36.67 \%$. During 2003-04, the incidence level was dramatically minimized and this trend was noticed in other sunflower growing areas as well. This indicated 
that the release of resistant hybrids/varieties through screening at Latur must have contributed to minimizing the disease incidence in farmers' fields.

Table 4: Survey of sunflower diseases in farmers' fields (2003-2004)

\begin{tabular}{llccc}
\hline $\begin{array}{l}\text { Ser. } \\
\text { no. }\end{array}$ & Location & Crop stage & $\begin{array}{r}\text { Hybrid/population } \\
\hline 1\end{array}$ & $\begin{array}{c}\text { Downy mildew incidence } \\
(\%)\end{array}$ \\
2 & Mahalangali & Flowering & Hybrid & 0.0 \\
3 & Gharni & Flowering & Hybrid & 0.0 \\
4 & Chakur & Flowering & Hybrid & Traces \\
5 & Shirur & Button & Hybrid & Traces \\
6 & Ahmadpur & Button & Hybrid & 5.0 \\
7 & Morewadi & Grain filling & Hybrid & Traces \\
8 & Handguli & Button & Variety & 3.0 \\
9 & Sukni & Flowering & Hybrid & 0.0 \\
10 & Dongarshella & Grain filling & Hybrid & 2.00 \\
11 & Udgir & Button & Hybrid & 0.0 \\
12 & Deoni & Flowering & Hybrid & Traces \\
13 & Valandi & Flowering & Hybrid & Traces \\
14 & Dhanegaon & Flowering & Variety & 5.0 \\
15 & Wilegaon & Grain filling & Variety & 2.0 \\
\hline
\end{tabular}

The sunflower downy mildew screening work initiated at Oilseeds Research Station, Latur has helped in identifying resistant hybrids and minimizing the disease problem in farmers' fields. Apart from this, the identification of resistant germplasm material and parental lines has helped sunflower breeders to initiate sunflower downy mildew disease resistant breeding program. Downy mildew is seed-borne in nature and release of resistant hybrids curbs the spread of the disease to new localities.

\section{ACKNOWLEDGEMENT}

The author is grateful to the Director of Research MAU, Parbhani (M.S.), and Dr. D.M. Hedge, Project Director, DOR Hyderabad, India, for their help and encouragement.

\section{REFERENCES}

Anonymous, 1996. Proceedings of Annual Group Meeting of Sunflower Research Workers, held at JNKVV, Jablapur, India. April, 13-15, 1996.

Anonymous, 1998. Proceedings of Annual Group Meeting of Sunflower Research Workers held at TANU, Coimbatore, India. April, 19-22, 1998.

Anonymous, 1999. Proceedings of Annual Group Meeting of Sunflower Research Workers, held at UAS, Dharwad, India. April, 26-28, 1999.

Anonymous, 2000. Proceedings of Annual Group Meeting of Sunflower Research Workers, held at PAU, Ludhiana, India. April, 26-29, 2000.

Anonymous, 2003. Proceedings of Annual Group Meeting of Sunflower Research Workers, held at TANU Coimbatore, India. April, 4-5, 2003. 
Anonymous, 2004(a). Proceedings of Maharashtra State (India) Variety Release Committee Meeting held in Bombay, India. Feb. 2003.

Anonymous, 2004(b). Annual Progress Report - Oilseeds Research Station Latur (M.S.) India. pp. 1-30.

Damodaram, T. and Hegde, D.M., 2002. Oil Seeds Situation; a statistical compendium 2000. Directorate of Oilseeds Research, Hyderabad (India). pp. 383.

Gulya, T., Berlin, N. and Lamey, A., 1994. Sunflower diseases. In: Sunflower Production Ext. Bulletin (Ed. Berjlund, D.R., 1994). North Dakota Agric. Experiment Station and North Dakota State Univ. 98 pp. 44-62.

Leepik, E.E., 1966. Origin and specialization of Plasmopara halstedii comples of the Compositae. FAO Plant. Prot. Bull. 14. 172

Mayee, C.D., 1988. Downy mildew of sunflower in India; Problem and approaches. Rev. Trop. Pl. Path. 54: 181-192.

Mayee, C.D. and Patil, M.A., 1986. Downy mildew of sunflower. Indian Phytopath. 39: 314.

Patil, M.A., Mayee, C.D. and Phad, H.B., 1992. Sunflower Downy Mildew Information Bulletin. Oilseeds Research Station, Latur (M.S.) India. pp. 76.

Ramanth, A.K., Lambat B.N., Mukewar and Indrarani, 1981. Interceptions of pathogenic fungi on imported seeds and planting material. Indian Phytopath. 34: 282-286.

Sackston, W.E., 1981. Downy mildew of sunflower. In: The Downy Mildews (Ed. Spancer, D.M., 1981.). Academic Press, London. pp. 545.

Shirshikar, S.P., 1997. Survey of downy mildew disease of sunflower in Marathwada region. J. Maharashtra Agric. Univ. 22 (1): 135-136.

Viranyi, F., 1990. Downy mildew of sunflower. In: Plant Diseases of International Importance (Ed. Chuge et al., 1980). Prentice Hall, Englewood Cliff, New Jersey, 363, pp. 328-340.

\title{
SITUACIÓN ACTUAL CONCERNIENTE AL TIZÓN DE GIRASOL EN LA INDIA
}

\author{
RESUMEN
}

Sobre la aparición del tizón en girasol en la India, fue reportado en el año 1986, para la región Marathwada, Estado Maharashtra, donde el girasol se cultiva activamente. La investigación realizada en dicha región, a lo largo de 199596 , mostró la intensidad del fenómeno de $36,67 \%$. De 1944 genotipos de girasol investigados, ocho híbridos y una población, que mostraron la resistencia hacia el tizón, y que tenían alto potencial para el rendimiento, fueron introducidos en la producción comercial en La India. La introducción de estos híbridos resistentes, contribuyó para disminuir la aparición del tizón en los campos de los granjeros. Actualmente, la presencia de esta enfermedad en los campos es mínima.

\section{SITUATION ACTUELLE DE LA ROUILLE DU TOURNESOL EN INDE}

\section{RÉSUMÉ}

La présence de la rouille du tournesol en Inde a été annoncée vers 1986 dans la région de Marathwada, des États Maharashtra où le tournesol fait l'objet d'une culture intensive. L'enquête effectuée dans cette région au cours des années 1995-96 a démontré que l'intensité du phénomène était de 36,67\%. Des 1944 génotypes examinés, huit hybrides et une population qui s'étaient révélés résistants à la maladie et qui avaient un bon potentiel de rendement ont été mis en production commerciale en Inde. L'introduction de ces hybrides résistants a contribué à la diminution de l'apparition de rouille dans les champs des fermiers. L'apparition de la maladie est actuellement minimale dans les champs. 